\title{
A Green Approach to the Production of 2-pyridone Derivatives Promoted by Infrared Irradiation
}

Fernando Hernández, ${ }^{1}$ Fabiola De la Cruz, ${ }^{1}$ Julio López, ${ }^{1}$ Eduardo Peña, ${ }^{1}$ Francisco Delgado, ${ }^{2}$ Yolanda Alcaraz, ${ }^{3}$ Juvencio Robles, ${ }^{3}$ Minerva Martínez-Alfaro, ${ }^{3}$ and Miguel A. Vázquez ${ }^{1 *}$

1 Departamento de Química, Universidad de Guanajuato, Noria Alta, S/N, Guanajuato, Gto. 36050, México. mvazquez@ugto. $\mathrm{mx}$

2 Departamento de Química Orgánica, Escuela Nacional de Ciencias Biológicas-IPN, Prol. Carpio y Plan de Ayala, S/N, 11340 México, D. F., México

3 Departamento de Farmacia, Universidad de Guanajuato, Noria Alta, S/N, Guanajuato, Gto. 36050, México.

Received November 14 $4^{\text {th }}, 2013$; Accepted February 17th 2014

\begin{abstract}
An alternative is presented for promoting a reaction with infrared irradiation to obtain different 4-aryl-3-cyano-5-ethoxycarbonyl-6-methyl-2-pyridone derivatives 9a-k. The process was carried out with a green approach from the corresponding $4 H$-pyrans, using mild reaction conditions and infrared irradiation as the energy source. In the first stage, the reaction produced 1,2,3,4-tetrahydropyridin-2-one derivatives $\mathbf{8 a - k}$, followed by an oxidative step to afford the target molecules in good yields. The structure of products 9a-k was confirmed by FT-IR, ${ }^{1} \mathrm{H}$ NMR and ${ }^{13} \mathrm{C}$ NMR spectroscopic techniques and X-ray diffraction. It was found that the efficiency of the reaction depends on the catalyst and the solvent, as well as on the aldehyde substituents.
\end{abstract}

Key words: $4 H$-pyrans, rearrangement, 2-pyridones, infrared irradiation, green approach.

\section{Introduction}

The heterocyclic skeleton containing a nitrogen atom is the basis of many essential pharmaceuticals and of many physiologically active natural products. Molecules containing heterocyclic substructures continue to be attractive targets for synthesis, since they often exhibit diverse and important biological properties. One important type of heterocycle that has shown a variety of biological activity is represented by 2-pyridones [1]. They exhibit a specific phosphodiesterase (PDE3) inhibitory activity and are a good alternative to the use of classic digitalis glycosides, such as amrinone and milrinone (Fig. 1), for acute treatment of congestive heart failure (CHF) [2].

Compounds with similar structural motifs exhibit significant pharmacological properties. For example, compounds $\mathbf{1}$ and $\mathbf{2}$ were evaluated for their inhibitory activity on the growth of human HT-29 colon tumor cells [3]. Analogues of 3, tested for inhibitory activity against thrombin, have proved to have an excellent selectivity against trypsin [4]. Likewise, compound $\mathbf{4}$ has proved to be a nonsteroidal inhibitor of $5 \alpha$-reductase and can be used for the treatment of benign prostatic hyperplasia (Fig. 1) [5]. Compound 5 has been used for the treatment of seborrheic dermatitis (Fig. 1) [6]. Compound 6 modulates serine hydrolase activity and also inhibits the activity of BuChE or AChE, while stimulating the activity of trypsin [7].

Currently, the preferred method for the preparation of 2pyridones is the Michael addition of acetonitrile derivatives
Resumen. Se reporta el uso de la irradiación infrarroja como un método de activación alternativa para obtener diferentes derivados 4-aril-3-ciano-5-etoxicarbonil-6-metil-2-piridonas $9 \mathbf{a}-\mathbf{k}$ con buenos rendimientos. El proceso se lleva a cabo con un enfoque verde a partir de los $4 \mathrm{H}$-piranos correspondientes, empleando condiciones de reacción suaves y la irradiación infrarroja como el promotor de la reacción, para producir, en una primera etapa, los derivados 1,2,3,4-tetrahidropiridin-2-onas 8a-k, seguido por un paso de oxidación, para generar las moléculas objetivo. La estructura de los productos 9a-k se confirmó por las técnicas espectroscópicas de FT-IR, RMN ${ }^{1} \mathrm{H}, \mathrm{RMN}{ }^{13} \mathrm{C}$ y difracción de rayos X. Se encontró que la eficiencia de la reacción depende del catalizador, del disolvente, así como de los sustituyentes del aldehído.

Palabras clave: $4 H$-piranos, transposición, 2-piridonas, irradiación infrarroja, proceso verde.

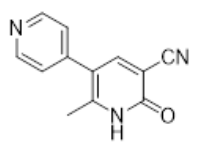

Milrinone

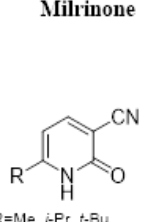

3

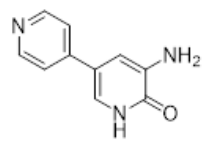

Amrinone

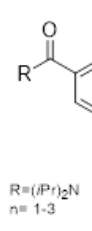

$R=(\mathbb{P r})_{2} \mathrm{~N}$
$n=1-3$

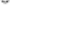

Fig. 1 The 2-pyridone moiety in various compounds with biological activity.

to an appropriate $\alpha, \beta$-unsaturated carbonyl substrate, and the subsequent hydrolytic cyclization followed by oxidative aromatization [8]. Alternatively, the treatment of $\beta$-oxo amides under Vilsmeier conditions yields 2-pyridones [9]. Other noteworthy methods have been reported, such as starting from the Blaise reaction intermediate [10], or the cyclization between BaylisHillman acetates and enamino esters or nitriles [11]. However, many of the established methods are carried out under harsh reaction conditions. For example, Degani et al. reported the 
synthesis of 3-cyano-2-pyridones using a guanidine based ionic liquid as catalyst [12].

The modification of fundamental synthetic reactions by using different energy sources represents one of the main focuses of our research group. In order to contribute to the development of environmentally benign methods, several reactions have been studied by our group, including the Knoevenagel condensation [13], the formation of $N$-benzylideneanilines [14], the use of $4 H$-pyran [15], and Diels-Alder reactions [16].

Encouraged by the aforementioned reports on the preparation of active pyridine compounds, we aimed to obtain some 2pyridone derivatives through a more environmentally friendly method. In the current contribution, we investigated infrared irradiation as a promoter of reactions to produce a variety of 4-aryl and (heteroaryl)-3-cyano-5-ethoxycarbonyl-6-methyl-2pyridones in good yields.

\section{Results and Discussion}

\section{The ring opening/closing process of $7 \mathrm{a}-\mathrm{k}$}

The synthesis of $4 H$-pyrans 7 has been previously reported [15], and we hypothesized that a rearrangement of 7 and the subsequent oxidation reaction would provide a synthetic route for yielding 4-aryl-3-cyano-5-ethoxycarbonyl-6-methyl-2-pyridones 9 under infrared irradiation. It was envisaged that for $4 H$-pyran $7 \mathbf{a}$ a sequential ring opening would be followed by a ring closing process. It was necessary to find a suitable catalyst for this rearrangement, for which purpose $p$-toluenesulfonic acid was initially tested [17], using IR irradiation as the energy source at $90{ }^{\circ} \mathrm{C}(50 \mathrm{~V}$, OSRAM R-20 bulb, $127 \mathrm{~V}, 250 \mathrm{~W}, \lambda$ $=1255.6 \mathrm{~nm}$ ) [18] for $60 \mathrm{~min}$ in the absence of solvent. The desired pyridone 8a was obtained as a mixture of diastereoisomers trans/cis in low yield (29\%), as observed from the ${ }^{1} \mathrm{H}$ NMR (300 MHz) analysis of the crude reaction mixture (Table 1 , entry 1$)$.

The reaction was carried out with different solvents in order to determine their effect. As shown in Table 1, the reaction was performed in $\mathrm{CHCl}_{3}$, THF, $\mathrm{CH}_{3} \mathrm{CN}$, dioxane, water and ethanol (entries 2-7) to analyze the catalytic activity of the acid and the medium best suited for the transformation. It was found that the reaction using ethanol as the solvent (Table 1, entry 7) resulted in the highest yields.

It is known that ultrasound can perform chemical transformations [19]. To demonstrate the efficiency and applicability of IR irradiation, we compared its use to that of other sources of energy. Previous reports [17] describe the ring opening followed by ring closure during the hydration and dehydration of the $4 \mathrm{H}$-pyran nucleus at $70^{\circ} \mathrm{C}$ for $7 \mathrm{~h}$, leading to 3, 4-dihydropyridone derivatives. With these thermal conditions, the results were similar to those found in the present study (Table 2, entry 2 ), in which the same conditions prevailed but with IR irradiation as the reaction promoter. An analysis of yields and reaction times shows that compared with the thermal method, with IR irradiation the reaction time is shortened and the product yield
Table 1. A comparative study of the effect of different solvents on the ring opening/closing of $7 \mathbf{a}^{\mathrm{a}}$

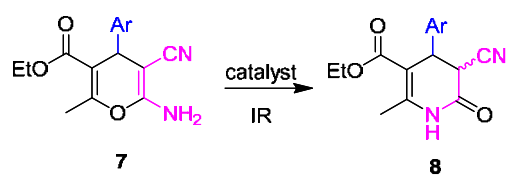

\begin{tabular}{cccc}
\hline Entry & Solvent & Reaction time & ${\text { Yield }(\%)^{\mathrm{b}}}^{\text {None }}$ \\
\hline 1 & $1.0 \mathrm{~h}$ & 29 \\
2 & $\mathrm{CHCl}_{3}$ & $12 \mathrm{~h}$ & 0 \\
3 & $\mathrm{THF}$ & $12 \mathrm{~h}$ & 0 \\
4 & $\mathrm{CH}_{3} \mathrm{CN}$ & $12 \mathrm{~h}$ & 0 \\
5 & Dioxane & $6 \mathrm{~h}$ & 55 \\
6 & Water & $2 \mathrm{~h}$ & 65 \\
7 & Ethanol & $10 \mathrm{~min}$ & 87 \\
\hline
\end{tabular}

aReaction conditions: $7 \mathbf{a}(1.5 \mathrm{mmol}), p$-toluenesulfonic acid $(0.15 \mathrm{mmol})$, and solvent $(3.0 \mathrm{~mL})$ under IR irradiation at $90{ }^{\circ} \mathrm{C}$ $(50 \mathrm{~V}) .{ }^{\mathrm{b}}$ After the recrystallization procedure, isolated yields were determined by NMR and correspond to the mixture of trans/cis adducts.

Table 2. Comparison of different sources of energy for the conversion of $7 \mathbf{a}$ to $8 \mathbf{a}^{\mathrm{a}}$

\begin{tabular}{ccccc}
\hline Entry & Energy source & $\mathrm{T} /{ }^{\circ} \mathrm{C}$ & $\mathrm{t} / \mathrm{h}$ & yield $(\%)^{\mathrm{b}}$ \\
\hline 1 & IR $(50 \mathrm{~V})$ & 90 & 0.1 & 86 \\
2 & Thermal & 70 & 0.5 & 72 \\
3 & Ultrasound & 70 & 0.4 & 80 \\
4 & r.t & 25 & 7 & 8 \\
\hline
\end{tabular}

aReaction conditions: 7a (1.5 mmol), $p$-toluenesulfonic acid $(0.15$ $\mathrm{mmol})$, and ethanol $(3.0 \mathrm{~mL}) .{ }^{\mathrm{b}}$ After the recrystallization procedure, isolated yields were determined by NMR and correspond to the mixture of trans/cis adducts.

is increased (Table 2, entry 1). It is important to mention that at $90{ }^{\circ} \mathrm{C}(50 \mathrm{~V})$ decomposition of the raw material and product begins.

On the other hand, several Brönsted-Lowry acids were screened, including sulfuric and hydrochloric acid, to assess their efficiency in the ring opening/closing of $7 \mathbf{a}$ (Table 3 ). We also studied the catalytic activity of iodine on the reaction. Hydrochloric acid was found somewhat better than iodine (yield $80 \%$ ), but the best results were obtained with sulfuric acid (yield 94\%). The latter catalyst at $10 \mathrm{~mol} \%$ was enough to push the reaction forward. Increasing the amount of catalyst (30\%) did not result in significant improvement in the yield (Table 3, entry 5), while reducing the amount of catalyst below $10 \mathrm{~mol} \%$ resulted in a lower yield (Table 3, entry 4). Iodine resulted in poor conversion of 8a (Table 3, entry 6).

The use of these optimal experimental conditions (IR irradiation, $90{ }^{\circ} \mathrm{C}, \mathrm{H}_{2} \mathrm{SO}_{4}-\mathrm{EtOH}$ ) for the reactions of different 6-amino-5-cyanopyrans $\mathbf{7 b}$-k afforded good yields of 4-aryl3-cyano-5-ethoxycarbonyl-6-methyl-3,4-dihydro-2-pyridones 
Table 3. Catalyst optimization for the conversion of 7a into $\mathbf{8 a} .^{\mathrm{a}}$

\begin{tabular}{ccccc}
\hline entry & catalyst & $\begin{array}{c}\text { catalyst } \\
(\mathrm{mol} \%)\end{array}$ & $\mathrm{t}(\mathrm{min})$ & ${\text { yield }(\%)^{\mathrm{b}}}$ \\
\hline 1 & $p$-TsOH (99\%) & 10 & 10 & 87 \\
2 & $\mathrm{HCl}(35 \%)$ & 10 & 10 & 80 \\
3 & $\mathrm{H}_{2} \mathrm{SO}_{4}(99 \%)$ & 10 & 5 & 94 \\
4 & $\mathrm{H}_{2} \mathrm{SO}_{4}(99 \%)$ & 5 & 20 & 65 \\
5 & $\mathrm{H}_{2} \mathrm{SO}_{4}(99 \%)$ & 30 & 7 & 95 \\
6 & $\mathrm{I}_{2}(99 \%)$ & 10 & 30 & 57 \\
\hline
\end{tabular}

${ }^{a}$ All entries were carried out using catalysts in ethanol as solvent, under IR irradiation. ${ }^{b}$ Determined by ${ }^{1} \mathrm{H}$ NMR of the crude reaction mixtures, corresponding to the mixture of trans/cis adducts.

$\mathbf{8 b}-\mathbf{k}$. The results (Table 4) indicate that both aryl and heteroaryl functional groups are suitable for the reaction.

Compounds 8a-k were isolated as a trans/cis mixture of adducts. Like their precursors, these compounds showed the same number of signals in the proton-decoupled ${ }^{13} \mathrm{C}$ NMR spectrum as with the ${ }^{1} \mathrm{H}$ NMR spectrum. The latter spectrum shows two new sets of signals at $\sim 10.80-10.40 \mathrm{ppm}$, corresponding to the NH protons (trans/cis), $\sim 5.05-4.57 \mathrm{ppm}$ (trans $J=7.5 \mathrm{~Hz})$ and $4.67-4.35 \mathrm{ppm}($ cis $J=5.5 \mathrm{~Hz})$. Furthermore, the infrared spectrums of 8a-k displayed carbonyl absorptions at $\sim 1721$ and $1662 \mathrm{~cm}^{-1}$, in contrast to the carbonyl absorption at $\sim 1676 \mathrm{~cm}^{-1}$ for $7 \mathbf{a}-\mathbf{k}$.

The proposed mechanism of rearrangement of $4 H$-pyrans is described in Scheme 1, involving a hydration process to produce the intermediary II, which then undergoes a condensation reaction to yield $\mathbf{8 a - k}$ [18].

Table 4. Relation between diasteroisomers cis/trans in $\mathbf{8 a - k}$, determined by NMR.

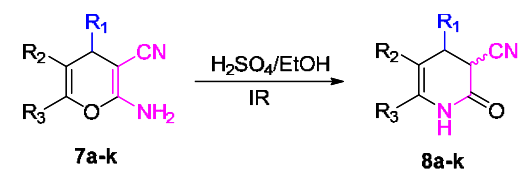

\begin{tabular}{cccccc}
\hline product & $\mathrm{R}_{1}$ & $\mathrm{R}_{2}$ & $\mathrm{R}_{3}$ & $\begin{array}{c}\text { Ratio } \\
\text { trans/cis }\end{array}$ & $\begin{array}{c}\text { yield } \\
(\%)^{\mathrm{a}}\end{array}$ \\
\hline $\mathbf{8 a}$ & $4-\mathrm{FC}_{6} \mathrm{H}_{4}$ & $-\mathrm{CO}_{2} \mathrm{Et}$ & $-\mathrm{CH}_{3}$ & $82 / 18$ & 85 \\
$\mathbf{8 b}$ & $4-\mathrm{BrC}_{6} \mathrm{H}_{4}$ & $-\mathrm{CO}_{2} \mathrm{Et}$ & $-\mathrm{CH}_{3}$ & $91 / 9$ & 91 \\
$\mathbf{8 c}$ & $3-\mathrm{NO}_{2} \mathrm{C}_{6} \mathrm{H}_{4}$ & $-\mathrm{CO}_{2} \mathrm{Et}$ & $-\mathrm{CH}_{3}$ & $82 / 18$ & 86 \\
$\mathbf{8 d}$ & $2-\mathrm{NO}_{2} \mathrm{C}_{6} \mathrm{H}_{4}$ & $-\mathrm{CO}_{2} \mathrm{Et}$ & $-\mathrm{CH}_{3}$ & $84 / 16$ & 90 \\
$\mathbf{8 e}$ & $\mathrm{C}_{6} \mathrm{H}_{5}$ & $-\mathrm{CO}_{2} \mathrm{Et}$ & $-\mathrm{CH}_{3}$ & $84 / 16$ & 86 \\
$\mathbf{8 f}$ & $n-\mathrm{propyl}$ & $-\mathrm{CO}_{2} \mathrm{Et}$ & $-\mathrm{CH}_{3}$ & $95 / 5$ & 72 \\
$\mathbf{8 g}$ & $4-\mathrm{CH}_{3} \mathrm{OC}_{6} \mathrm{H}_{4}$ & $-\mathrm{CO}_{2} \mathrm{Et}$ & $-\mathrm{CH}_{3}$ & $89 / 11$ & 86 \\
$\mathbf{8 h}$ & $2,4-\mathrm{Cl}_{2} \mathrm{C}_{6} \mathrm{H}_{3}$ & $-\mathrm{CO}_{2} \mathrm{Et}$ & $-\mathrm{CH}_{3}$ & $86 / 14$ & 93 \\
$\mathbf{8 i}$ & $3-\mathrm{NO}_{2} \mathrm{C}_{6} \mathrm{H}_{4}$ & $-\mathrm{COCH}_{3}$ & $-\mathrm{CH}_{3}$ & $84 / 16$ & 80 \\
$\mathbf{8 j}$ & $3-\mathrm{NO}_{2} \mathrm{C}_{6} \mathrm{H}_{4}$ & $-\mathrm{CO}_{2} \mathrm{CH}$ & $-\mathrm{CH}_{2} \mathrm{CO}_{2} \mathrm{CH}_{3}$ & $84 / 16$ & 85 \\
$\mathbf{8 k}$ & $4-\mathrm{NO}_{2} \mathrm{C}_{6} \mathrm{H}_{4}$ & $-\mathrm{CO}_{2} \mathrm{Et}$ & $-\mathrm{CH}_{3}$ & $84 / 16$ & 87 \\
\hline
\end{tabular}

${ }^{\text {a }}$ Determined after recrystallization by ${ }^{1} \mathrm{H}$ NMR, corresponding to the mixture of trans/cis adducts.

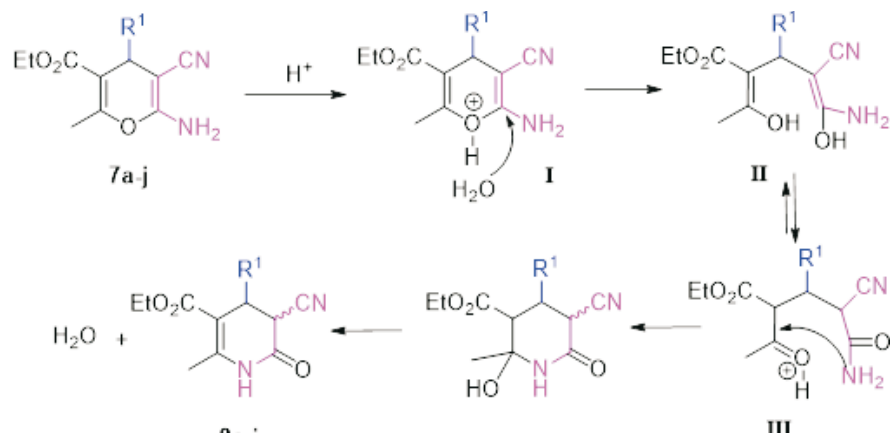

Scheme 1. Plausible mechanistic course for the synthesis of 3,4-dihydropyridin-2-ones.

\section{Oxidation of 4-aryl-3-cyano-5-ethoxycarbonyl-6-methyl- 3,4-dihydro-2-pyridones 8a-k}

The ring opening/closing of 7a proved to be an efficient process for building the 4-aryl-3-cyano-5-ethoxycarbonyl-6-methyl3,4-dihydro-2-pyridone scaffold. 3,4-dihydro-2-pyridones 8a$\mathbf{k}$ possess a core that may be expected to undergo an oxidation reaction.

In the course of the current study, an initial attempt was made to oxidize the adduct $\mathbf{8 a}$ with nitric acid on silica gel under solvent-free conditions with infrared irradiation at 100 ${ }^{\circ} \mathrm{C}(60 \mathrm{~V})$. The starting material began to decompose after 10 min of reaction (Table 5, entry 1). Thereafter, we employed nitric acid on silica gel in EtOH as the solvent at reflux (60 V) and at $70{ }^{\circ} \mathrm{C}(30 \mathrm{~V})$ for $2-3 \mathrm{~h}$ to give $9 \mathrm{a}$ in low yields after purification on column chromatography (Table 5, entries 2 and 3 ). In order to induce aromatization, adduct $9 \mathbf{a}$ was treated with 2,3-dichloro-5,6-dicyano-1,4-benzoquinone (DDQ), employing ethanol as the solvent, under infrared irradiation for $10 \mathrm{~min}$ to give 9a in good yield ( $80 \%$; Table 5 , entry 4$)$.

In order to investigate the scope and limitations of this oxidation reaction, as well as to identify the possible effect induced by other substrates on the formation of compounds $\mathbf{9 b -}$ $\mathbf{k}$, the reaction was carried out with substrates $\mathbf{9 b}-\mathbf{k}$ under the same reaction conditions. The behavior observed was similar to

Table 5. Oxidation of $8 \mathbf{a}$ using various reaction conditions.

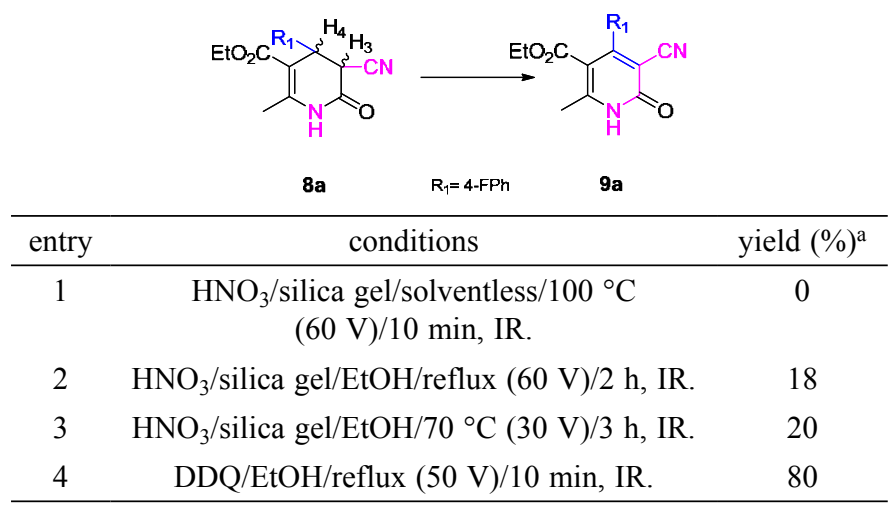

${ }^{\text {a}}$ Yields refer to the pure isolated product. 
Table 6. Synthesis of 5-cyano-pyridin-2-ones 9a-k.

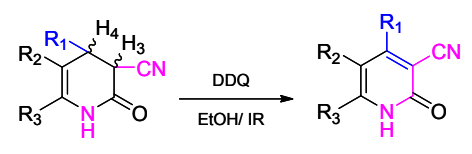

\begin{tabular}{lllll}
\multicolumn{3}{c}{ 8a-k } & \multicolumn{2}{c}{ 9a-k } \\
\hline Product & $\mathrm{R}_{1}$ & $\mathrm{R}_{2}$ & $\mathrm{R}_{3}$ & Yield (\%) \\
\hline 9a & $4-\mathrm{FC}_{6} \mathrm{H}_{4}$ & $-\mathrm{CO}_{2} \mathrm{Et}$ & $-\mathrm{CH}_{3}$ & 82 \\
$\mathbf{9 b}$ & $4-\mathrm{BrC}_{6} \mathrm{H}_{4}$ & $-\mathrm{CO}_{2} \mathrm{Et}$ & $-\mathrm{CH}_{3}$ & 84 \\
$\mathbf{9 c}$ & $3-\mathrm{NO}_{2} \mathrm{C}_{6} \mathrm{H}_{4}$ & $-\mathrm{CO}_{2} \mathrm{Et}$ & $-\mathrm{CH}_{3}$ & 83 \\
$\mathbf{9 d}$ & $2-\mathrm{NO}_{2} \mathrm{C}_{6} \mathrm{H}_{4}$ & $-\mathrm{CO}_{2} \mathrm{Et}$ & $-\mathrm{CH}_{3}$ & 85 \\
$\mathbf{9 e}$ & $\mathrm{C}_{6} \mathrm{H}_{5}$ & $-\mathrm{CO}_{2} \mathrm{Et}$ & $-\mathrm{CH}_{3}$ & 81 \\
$\mathbf{9 f}$ & $n-\mathrm{propyl}$ & $-\mathrm{CO}_{2} \mathrm{Et}$ & $-\mathrm{CH}_{3}$ & 70 \\
$\mathbf{9 g}$ & $4-\mathrm{CH}_{3} \mathrm{OC}_{6} \mathrm{H}_{4}$ & $-\mathrm{CO}_{2} \mathrm{Et}$ & $-\mathrm{CH}_{3}$ & 75 \\
9h & $2,4-\mathrm{Cl}_{2} \mathrm{C}_{6} \mathrm{H}_{3}$ & $-\mathrm{CO}_{2} \mathrm{Et}$ & $-\mathrm{CH}_{3}$ & 83 \\
$\mathbf{9 i}$ & $3-\mathrm{NO}_{2} \mathrm{C}_{6} \mathrm{H}_{4}$ & $-\mathrm{COCH}_{3}$ & $-\mathrm{CH}_{3}$ & 80 \\
$\mathbf{9 j}$ & $3-\mathrm{NO}_{2} \mathrm{C}_{6} \mathrm{H}_{4}$ & $-\mathrm{CO}_{2} \mathrm{CH} \mathrm{H}_{3}$ & $-\mathrm{CH}_{2} \mathrm{CO}_{2} \mathrm{CH}_{3}$ & 82 \\
$\mathbf{9 k}$ & $4-\mathrm{NO}_{2} \mathrm{C}_{6} \mathrm{H}_{4}$ & $-\mathrm{CO}_{2} \mathrm{Et}$ & $-\mathrm{CH}_{3}$ & 91 \\
\hline
\end{tabular}

that found with $\mathbf{8 a}$, resulting in the formation of adducts $\mathbf{9 b - k}$ as single products in comparable yields (Table 6). It is evident that the reaction proceeded smoothly for both electron rich and electron deficient aryl and heteroaryl aldehydes that have a 1,3-dicarbonylic moiety. There was reasonably good yield after purification with column chromatography.

The compounds were analyzed by various spectroscopic methods. The IR spectrum of 9a exhibited bands at 3079, 2228 and $1662 \mathrm{~cm}^{-1}$, indicating the presence of $\mathrm{NH}, \mathrm{C} \equiv \mathrm{N}$ and $\mathrm{C}=\mathrm{O}$ functionalities, respectively. The ${ }^{1} \mathrm{H}$ NMR spectrum evidenced the disappearance of the multiplicity of $\mathrm{H}-3$ and $\mathrm{H}-4$, the characteristic singlet at $\delta 3.81 \mathrm{ppm}$ due to a methyl group, and the presence of an ethoxy group at 0.72 and $2.46 \mathrm{ppm}$. The spectral data and physical properties of $9 \mathbf{a}-\mathbf{k}$ can be seen in the experimental and supplementary information sections.

A single-crystal X-ray diffraction crystallography of compound 9b allowed us to confirm its structure (Fig. 2.) [20].

\section{Conclusions}

In summary, we have developed a simple, efficient and rapid method for the synthesis of 2-pyridone derivatives in moderate to excellent yields using IR irradiation. This simple procedure with some aspects of a green approach has the advantage of requiring only mild conditions during the reaction, using a catalytic quantity of $\mathrm{H}_{2} \mathrm{SO}_{4}$ for the first stage and DDQ.

\section{Experimental Section}

Melting points were determined on an electrothermal digital 90100 melting point apparatus and were uncorrected. IR spectra were recorded on a Perkin-Elmer Spectrum 100 FT-IR spectrophotometer. NMR spectra were recorded on Varian Gemini $(300 \mathrm{MHz})$ and Varian VNMR System $(500 \mathrm{MHz})$ instruments, using solutions in DMSO- $\mathrm{d}_{6}$ and $\mathrm{CDCl}_{3}$ with $\mathrm{Me}_{4} \mathrm{Si}$ as internal standard. High-resolution mass spectra (HRMS) were obtained with a JSM-GCMate II mass spectrometer, and electron impact techniques $(70 \mathrm{eV})$ were employed. X-ray data were collected on an Oxford Diffraction Xcalibur S single-crystal X-ray diffractometer. For reactions with ultrasound heating, Bransonic equipment was used (Branson model 1510). TLC analyses were performed using silica plates and were visualized using UV $(254 \mathrm{~nm})$ or iodine.

\section{General procedure for the preparation of ethyl-5-cyano- 4-(aryl)-2-methyl-6-oxo-1,4,5,6-tetrahydropyridine-3- carboxylates (8a-k) using IR irradiation}

A mixture of $4 H$-pyran $7 \mathbf{a}-\mathbf{k}(1.50 \mathrm{mmol})$ and concentrated sulfuric acid $(10 \mathrm{~mol} \%)$ in $\mathrm{EtOH}(3 \mathrm{~mL})$ was IR irradiated at $80{ }^{\circ} \mathrm{C}(50 \mathrm{~V})$ for 15 minutes. The progress of the reaction was monitored by TLC (hexane/EtOAc, 7/3). The reaction was purified by recrystallization using a $95 / 5$ ratio of $\mathrm{H}_{2} \mathrm{O} / \mathrm{EtOH}$ to obtain the mixture of the two diastereoisomers. The solid obtained was collected by vacuum filtration, and then the product was allowed to dry before quantification.

\section{Procedure for the preparation of ethyl-5-cyano-4-(aryl)- 2-methyl-6-oxo-1,4,5,6-tetrahydropyridine-3-carboxylate (8a) using ultrasound}

A mixture of $4 H$-pyran $7 \mathbf{a}(1.50 \mathrm{mmol})$ and $p$-toluenesulfonic acid $(15 \mathrm{~mol} \%)$ in $\mathrm{EtOH}(3 \mathrm{~mL})$ was heated to $50{ }^{\circ} \mathrm{C}$ and

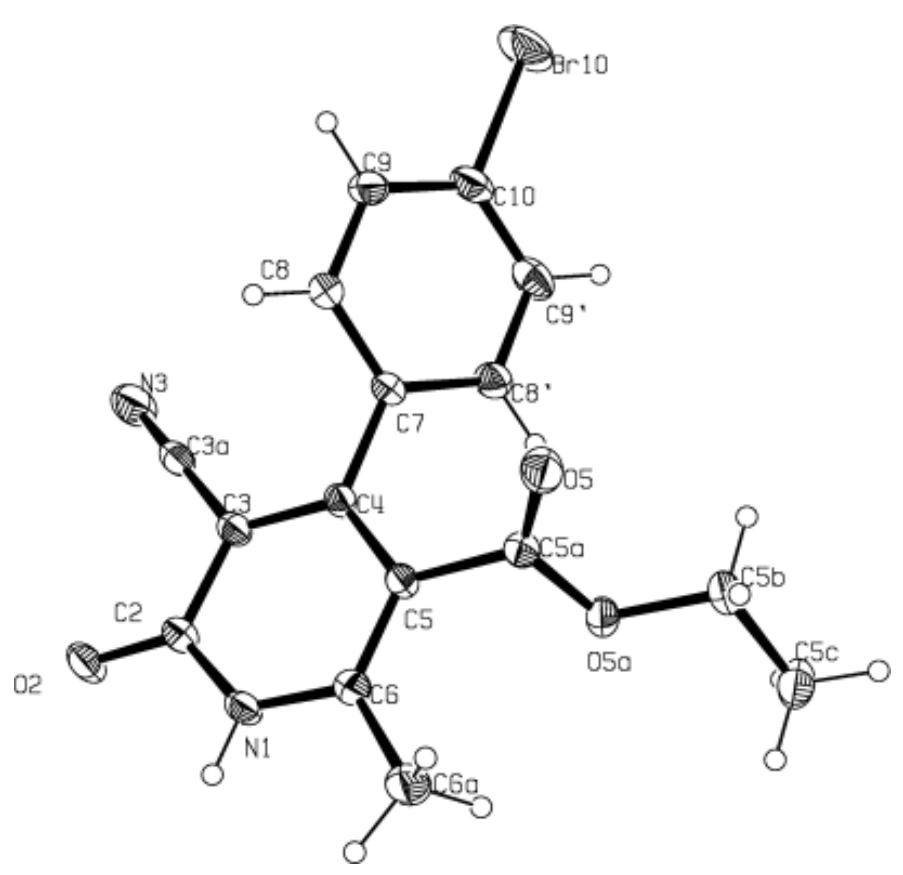

Fig. 2. The X-ray structure of $9 \mathrm{~b}$. 
maintained at that temperature for 25 minutes. The progress of the reaction was monitored by TLC (hexane/EtOAc, 7/3). The reaction was purified by recrystallization using a 95/5 ratio of $\mathrm{H}_{2} \mathrm{O} / \mathrm{EtOH}$ to obtain the mixture of the two diastereoisomers. The solid obtained was collected by vacuum filtration, and then the product was allowed to dry before quantification.

Procedure for the preparation of ethyl-5-cyano-4-(aryl)2-methyl-6-oxo-1,4,5,6-tetrahydropyridine-3-carboxylate (8a) by conventional heating

A mixture of $4 H$-pyran $7 \mathbf{a}(1.50 \mathrm{mmol})$ and $p$-toluenesulfonic acid $(15 \mathrm{~mol} \%)$ in $\mathrm{EtOH}(3 \mathrm{~mL})$ was heated at reflux for 25 minutes. The progress of the reaction was monitored by TLC (hexane/EtOAc, 7/3). The reaction was purified by recrystallization using a $95 / 5$ ratio of $\mathrm{H}_{2} \mathrm{O} / \mathrm{EtOH}$ to obtain the mixture of the two diastereoisomers. The solid obtained was collected by vacuum filtration, and then the product was allowed to dry before quantification.

General procedure for the preparation of ethyl-5-cyano-2methyl-6-oxo-4-hetero and carboaryl-1,6-dihydropyridine3-carboxylates (9a-k)

A mixture of 1,2,3,4-tetrahydropyridin-2-ones (8a-k) (1.52 $\mathrm{mmol})$, ethanol $(3 \mathrm{~mL})$ and DDQ $(1.52 \mathrm{mmol})$ was IR irradiated at $90{ }^{\circ} \mathrm{C}(50 \mathrm{~V})$ for 10 minutes. The progress of the reaction was monitored by TLC (EtOAc/hexane 5/5). The reaction was purified by column chromatography (hexane/AcOEt, 1/1). The solid obtained was collected under vacuum.

\section{Ethyl-5-cyano-4-(4-fluorophenyl)-2-methyl-6-oxo-1,6-} dihydropyridine-3-carboxylate (9a)

White solid, m.p. $215-216{ }^{\circ} \mathrm{C} .{ }^{1} \mathrm{H}$ NMR (500 MHz, DMSO- $\left.d_{6}\right)$ : $\delta 13.12(\mathrm{~s}, 1 \mathrm{H}), 7.40-7.36(\mathrm{~m}, 4 \mathrm{H}), 3.87(\mathrm{q}, J=7.1 \mathrm{~Hz}, 2 \mathrm{H})$, $2.43(\mathrm{~s}, 3 \mathrm{H}), 0.78(\mathrm{t}, J=7.1 \mathrm{~Hz}, 3 \mathrm{H}) .{ }^{13} \mathrm{C} \mathrm{NMR}(125 \mathrm{MHz}$, DMSO- $\left.d_{6}\right): \delta 164.79,163.66,161.70,158.47,153.44,132.33$, $129.68,115.55,115.37,112.01,100.87,60.95,18.27,13.19$. IR $\left(\mathrm{KBr}, \mathrm{cm}^{-1}\right): v 2996,2230,1708,1650,1284 . \mathrm{HRMS}\left(\mathrm{EI}^{+}\right)$ calculated for $\mathrm{C}_{16} \mathrm{H}_{13} \mathrm{FN}_{2} \mathrm{O}_{3} 300.0910$, found $\left(\mathrm{M}^{+}\right) 300.0904$ (2.0 ppm error).

Ethyl 4-(4-bromophenyl)-5-cyano-2-methyl-6-oxo-1,6dihydropyridine-3-carboxylate $(9 \mathrm{~b})$

Yellow crystal, m.p. $228-229^{\circ} \mathrm{C} .{ }^{1} \mathrm{H}$ NMR $(300 \mathrm{MHz}$, DMSO$\left.d_{6}\right): \delta 7.74(\mathrm{~d}, J=8.4 \mathrm{~Hz}, 2 \mathrm{H}), 7.31(\mathrm{~d}, J=8.4 \mathrm{~Hz}, 2 \mathrm{H}), 3.87$ $(\mathrm{q}, J=7.2 \mathrm{~Hz}, 2 \mathrm{H}), 2.44(\mathrm{~s}, 3 \mathrm{H}), 0.76(\mathrm{t}, J=7.1 \mathrm{~Hz}, 3 \mathrm{H}) .{ }^{13} \mathrm{C}$ NMR (75 MHz, DMSO- $\left.d_{6}\right): \delta 164.64,159.78,158.29,153.96$, 135.25, 131.47, 129.36, 122.92, 115.36, 111.51, 100.56, 60.94, 18.41, 13.09. IR (KBr, cm $\left.{ }^{-1}\right): v$ 2996, 2230, 1708, 1650, 1284. HRMS $\left(\mathrm{EI}^{+}\right.$) calculated for $\mathrm{C}_{16} \mathrm{H}_{13} \mathrm{BrN}_{2} \mathrm{O}_{3} 360.0110$, found $\left(\mathrm{M}^{+}\right) 360.0103$ (2.0 ppm error).
Ethyl 5-cyano-2-methyl-4-(3-nitrophenyl)-6-oxo-1,6dihydropyridine-3-carboxylate (9c)

Red solid, m.p. $227-228{ }^{\circ} \mathrm{C} .{ }^{1} \mathrm{H}$ NMR (300 MHz, DMSO- $\left.d_{6}\right)$ : $\delta 13.28(\mathrm{~s}, 1 \mathrm{H}), 8.41(\mathrm{~m}, 1 \mathrm{H}) 8.24(\mathrm{~s}, 1 \mathrm{H}), 7.88(\mathrm{~s}, 2 \mathrm{H}), 3.88$ $(\mathrm{q}, J=7.2 \mathrm{~Hz}, 2 \mathrm{H}), 2.51(\mathrm{~s}, 3 \mathrm{H}), 0.74(\mathrm{t}, J=7.5 \mathrm{~Hz}, 3 \mathrm{H}) .{ }^{13} \mathrm{C}$ NMR (75 MHz, DMSO- $\left.d_{6}\right): \delta 164.29,159.51,157.21,154.79$, 147.50, 137.75, 134.07, 130.41, 124.13, 122.10, 115.15, 111.17, $101.39,60.96,18.64,13.12$. IR $\left(\mathrm{KBr}, \mathrm{cm}^{-1}\right): v$ 2901, 2229, 1728, 1671, 1288. HRMS $\left(\mathrm{EI}^{+}\right)$calculated for $\mathrm{C}_{16} \mathrm{H}_{13} \mathrm{~N}_{3} \mathrm{O}_{5}$ 327.0855, found $\left(\mathrm{M}^{+}\right) 327.0850$ (1.5 ppm error).

Ethyl 5-cyano-2-methyl-4-(2-nitrophenyl)-6-oxo-1,6dihydropyridine-3-carboxylate (9d)

Brown solid, m.p. 225-226 ${ }^{\circ} \mathrm{C} .{ }^{1} \mathrm{H}$ NMR (500 MHz, DMSO$\left.d_{6}\right): \delta 13.29(\mathrm{~s}, 1 \mathrm{H}), \delta 8.35(\mathrm{~d}, J=8.3 \mathrm{~Hz}, 1 \mathrm{H}), 7.93(\mathrm{t}, J=7.6$ $\mathrm{Hz}, 1 \mathrm{H}), 7.82(\mathrm{td}, J=8.0,0.9 \mathrm{~Hz}, 1 \mathrm{H}), 7.52(\mathrm{~d}, J=7.6 \mathrm{~Hz}$, $1 \mathrm{H}), 3.82(\mathrm{q}, J=7.1 \mathrm{~Hz}, 2 \mathrm{H}), 2.56(\mathrm{~s}, 3 \mathrm{H}), 0.74(\mathrm{t}, J=7.1$ $\mathrm{Hz}, 3 \mathrm{H}) .{ }^{13} \mathrm{C}$ NMR $\left(125 \mathrm{MHz}, \mathrm{DMSO}-d_{6}\right): \delta 163.62,159.28$, 158.57, 156.18, 146.07, 134.81, 131.80, 130.87, 129.78, 124.71, $114.77,109.74,100.78,60.90,19.33,13.13$. IR $\left(\mathrm{KBr}, \mathrm{cm}^{-1}\right)$ : $v$ 2941, 2230, 1720, 1660, 1284. HRMS $\left(\mathrm{EI}^{+}\right)$calculated for $\mathrm{C}_{16} \mathrm{H}_{13} \mathrm{~N}_{3} \mathrm{O}_{5} 327.0855$, found $\left(\mathrm{M}^{+}\right) 327.0850$ (1.5 ppm error).

Ethyl 5-cyano-2-methyl-6-oxo-4-phenyl-1,6dihydropyridine-3-carboxylate (9e) [21]

Brown solid, m.p. 217-218 ${ }^{\circ} \mathrm{C} .{ }^{1} \mathrm{H}$ NMR (500 MHz, DMSO$\left.d_{6}\right): \delta 7.52-7.48(\mathrm{~m}, 3 \mathrm{H}), 7.33-7.30(\mathrm{~m}, 2 \mathrm{H}), 3.81(\mathrm{q}, J=7.1$ $\mathrm{Hz}, 2 \mathrm{H}), 0.70$ (t, $J=7.1 \mathrm{~Hz}, 3 \mathrm{H}) .{ }^{13} \mathrm{C}$ NMR (125 MHz, DMSO$\left.d_{6}\right): \delta 164.87,159.76,159.42,153.11,135.88,129.45,128.45$, $127.14,115.37,112.06,100.56,60.86,30.66,18.19$. IR (KBr, $\left.\mathrm{cm}^{-1}\right): v 3210,2229,1728,1641,1285$.

Ethyl 5-cyano-2-methyl-6-oxo-4-propyl-1,6dihydropyridine-3-carboxylate (9f)

White solid, m.p. $161-162{ }^{\circ} \mathrm{C} .{ }^{1} \mathrm{H}$ NMR (500 MHz, DMSO- $\left.d_{6}\right)$ : $\delta 4.28(\mathrm{q}, J=7.1 \mathrm{~Hz}, 1 \mathrm{H}), 2.69-2.61(\mathrm{~m}, 1 \mathrm{H}), 2.31(\mathrm{~s}, 3 \mathrm{H})$, $1.59-1.47(\mathrm{~m}, 1 \mathrm{H}), 1.27(\mathrm{t}, J=7.1 \mathrm{~Hz}, 1 \mathrm{H}), 0.91(\mathrm{t}, J=7.4$ $\mathrm{Hz}, 1 \mathrm{H}) .{ }^{13} \mathrm{C}$ NMR $\left(125 \mathrm{MHz}, \mathrm{DMSO}-d_{6}\right): \delta 165.21,161.60$, $159.77,152.78,115.34,111.79,100.65,61.48,34.80,22.74$, 18.48, 13.82, 13.78. IR (KBr, $\left.\mathrm{cm}^{-1}\right): v 2977,2229,1720,1658$, 1287. HRMS ( $\left.\mathrm{EI}^{+}\right)$calculated for $\mathrm{C}_{13} \mathrm{H}_{16} \mathrm{~N}_{2} \mathrm{O}_{3} 248.1161$, found $\left(\mathrm{M}^{+}\right) 248.1155$ (2.4 ppm error).

Ethyl 5-cyano-4-(4-methoxyphenyl)-2-methyl-6-oxo-1,6dihydropyridine-3-carboxylate (9g) [21]

White solid, m.p. 217-218 ${ }^{\circ} \mathrm{C} .{ }^{1} \mathrm{H}$ NMR (300 MHz, DMSO$\left.d_{6}\right): \delta 13.03(\mathrm{~s}, 1 \mathrm{H}), 7.29(\mathrm{~d}, J=8.1 \mathrm{~Hz}, 2 \mathrm{H}), 7.06(\mathrm{~d}, J=$ $8.7 \mathrm{~Hz}, 2 \mathrm{H}), 3.89$ (q, $J=6.9 \mathrm{~Hz}, 2 \mathrm{H}), 3.89$ (s, 3H), 2.40 (s, $3 \mathrm{H}), 0.79(\mathrm{t}, J=6.9 \mathrm{~Hz}, 3 \mathrm{H}) .{ }^{13} \mathrm{C}$ NMR $(75 \mathrm{MHz}$, DMSO$\left.d_{6}\right): \delta 165.18,160.30,159.94,159.08,152.58,128.87,127.82$, $115.71,113.90,111.37,101.24,60.95,55.32,18.06,13.26$. IR $\left(\mathrm{KBr}, \mathrm{cm}^{-1}\right): v$ 3009, 2226, 1722, 1666, 1295. 
Ethyl 5-cyano-4-(2,4-dichlorophenyl)-2-methyl-6-oxo-1,6dihydropyridine-3-carboxylate $(9 \mathrm{~h})$

Brown solid, m.p. 235-237 ${ }^{\circ} \mathrm{C} .{ }^{1} \mathrm{H}$ NMR (300 MHz, DMSO$\left.d_{6}\right): \delta 13.33(\mathrm{~s}, 1 \mathrm{H}), 7.83(\mathrm{~d}, J=1.5 \mathrm{~Hz}, 1 \mathrm{H}), 7.585(\mathrm{dd}, J=$ 8.4, $1.5 \mathrm{~Hz}, 1 \mathrm{H}), 7.43(\mathrm{~d}, J=8.4 \mathrm{~Hz}, 1 \mathrm{H}), 3.90(\mathrm{q}, J=7.2 \mathrm{~Hz}$, 2H), 2.54 (s, 3H), $0.80(\mathrm{t}, J=6.9 \mathrm{~Hz}, 3 \mathrm{H}) .{ }^{13} \mathrm{C} \mathrm{NMR}(75 \mathrm{MHz}$, DMSO- $\left.d_{6}\right): \delta 163.67,159.34,156.54,156.03,134.64,134.49$, $131.87,130.43,128.89,127.59,114.63,110.72,101.63,60.84$, 19.10, 13.07. IR (KBr, cm $\left.{ }^{-1}\right): v 2988,2230,1722,1655,1284$. HRMS $\left(\mathrm{EI}^{+}\right)$calculated for $\mathrm{C}_{16} \mathrm{H}_{12} \mathrm{Cl}_{2} \mathrm{~N}_{2} \mathrm{O}_{3} 350.0225$, found $\left(\mathrm{M}^{+}\right) 350.0220$ (1.4 ppm error).

\section{5-acetyl-6-methyl-4-(3-nitrophenyl)-2-oxo-1,2- dihydropyridine-3-carbonitrile (9i)}

White solid, m.p. 258-260 ${ }^{\circ} \mathrm{C} .{ }^{1} \mathrm{H}$ NMR (300 MHz, DMSO$\left.d_{6}\right): \delta 13.18(\mathrm{~s}, 1 \mathrm{H}), 8.40(\mathrm{~m}, 1 \mathrm{H}) 8.27(\mathrm{~d}, J=1.2 \mathrm{~Hz}, 1 \mathrm{H})$, 7.89 (s, 2H), 2.38 (s, 3H), $1.87(\mathrm{~s}, 3 \mathrm{H}) .{ }^{13} \mathrm{C}$ NMR $(75 \mathrm{MHz}$, DMSO- $\left.d_{6}\right): \delta 200.75,160.27,156.62,152.56,147.37,137.31$, 135.36, 131.50, 125.53, 123.57, 116.03, 112.17, 32.74, 18.91 . HRMS $\left(\mathrm{EI}^{+}\right)$calculated for $\mathrm{C}_{15} \mathrm{H}_{11} \mathrm{~N}_{3} \mathrm{O}_{4} 297.0750$, found $\left(\mathrm{M}^{+}\right)$ 297.0743 (2.4 ppm error).

\section{Ethyl-5-cyano-2-methyl-4-(4-nitrophenyl)-6-oxo-1,6- dihydropyridine-3-carboxylate (9k) [21]}

Brown solid; $\mathrm{mp} 208-210^{\circ} \mathrm{C}$; IR (KBr): 2254, $1651,1283 \mathrm{~cm}^{-1}$; ${ }^{1} \mathrm{H}$ NMR (DMSO-d $\left.6,200 \mathrm{MHz}\right) \delta 13.13(\mathrm{~s}, 1 \mathrm{H}), 8.46$ (d, $J=8.4$ $\mathrm{Hz}, 2 \mathrm{H}), 7.74$ (d, 2H, $J=8.4 \mathrm{~Hz}), 3.92$ (q, 2H, $J=7 \mathrm{~Hz}), 2.54$ $(\mathrm{s}, 3 \mathrm{H}), 0.80(\mathrm{t}, 3 \mathrm{H}, J=7 \mathrm{~Hz}) ;{ }^{13} \mathrm{C} \mathrm{NMR}\left(\mathrm{CDCl}_{3}, 50 \mathrm{MHz}\right): \delta$ $164.2,159.4,157.8,154.9,147.9,142.8,128.9,123.6,115.0$, $110.9,101.0,61.05,18.7,13.1$.

X-ray Structure Study of 9b. A single crystal, obtained by the slow evaporation of a concentrated solution of $\mathbf{9 b}$ ( $n$-hexane/ AcOEt, pale yellow), was mounted on glass fibers. Crystallographic measurements were performed on an Oxford Diffraction Xcalibur S single-crystal X-ray diffractometer using MoK $\backslash \alpha$ radiation (graphite crystal monochromator, $\lambda=0.71073$ $\AA$ ) at room temperature. Three standard reflections, which were monitored periodically, showed no change during data collection. Unit cell parameters were obtained from least-squares refinement of 26 reflections in the range $2^{\circ}<2 \theta<20^{\circ}$. Intensities were corrected for Lorentz and polarization effects. No absorption correction was applied. Anisotropic temperature factors were introduced for all non-hydrogen atoms. Hydrogen atoms were placed in idealized positions and their atomic coordinates refined. Structures were solved using the SHELXTL, [22] SHELX97, [23] or SIR92, [24] programs implemented in the WinGX suite[25], and refined using SHELXTL or SHELX97 within WinGX on a personal computer. In all cases ORTEP and packing diagrams were made with PLATON and ORTEP-3 [26].

\section{Acknowledgments}

We thank Marcos Flores-Álamo for his help with the X-ray analyses and Bruce Allan Larsen for revising the English of the manuscript. M.A.V., M.M.A and J.R acknowledge financial support from CONACYT (Grant 168474) and UGto-DAIP (Grant 281/13). F.H thanks CONACYT for a graduate scholarship (No. 482137).

\section{References and Notes}

1. a) Li, Z.; Liu, Z.; Cho, D. W.; Zou, J.; Gong, M.; Breece, R. M.; Galkin, A.; Li, L.; Zhao, H.; Maestas, G. D.; Tierney, D. L.; Herzberg, O.; Mariano, D. D.; Mariano, P. S. J. Inorg. Biochem. 2011, 105, 509-517. b) Ando, M.; Sato, N.; Nagase, T.; Nagai, K.; Ishikawa, S.; Ta-kahashi, H.; Ohtake, N.; Ito, J.; Hirayama, M.; Mitobe, Y.; Matsushita, H. H.; Tadano, K.; Fujino, N.; Tanaka, S.; Kanatani, A.; Fukami, T. Bioorg. Med. Chem. 2009, 17, 61066122. c) Abadi, A. H.; Ibrahim, T. M.; Abouzid, K. M.; Lehmann, J.; Tinsley, H. N.; Gary, B. D.; Piazza, G. A. Bioorg. Med. Chem. 2009, 17, 5974-5982. d) Jessen, H. J.; Schumacher, A.; Schmid, F.; Pfaltz, A.; Gademann, K. Org. Lett. 2011, 13, 16, 4368-4370. e) Goldstein, D. M.; Soth M.; Nolan-Dewdney, T. G.; Kuglstatter, A.; Arzeno, H.; Chen, J.; Bingenheimer, W.; Dalrymple, S. A.; Dunn, J.; Farrell, R.; Frauchiger, S.; Fargue, J. L.; Ghate, M.; Graves, B.; Hill, R. J.; Li, F.; Litman, R.; Loe, B.; McIntosh, J.; McWeeney, D.; Papp, E.; Park, J.; Reese, H.F.; Roberts, R.T.; Rotstein, D.; Pablo, B.S.; Sarma, K.; Stahl, M.; Sung, M. L.; Suttman, R. T.; Sjogren, E. B.; Tan, Y.; Trejo, A.; Welch, M.; Weller, P.; Wong, B. R.; Zecic, H. J. Med. Chem. 2011, 54, 2255-2265. f) Hernández, F.; Sánchez, A.; Rendón-Vallejo, P.; Millán-Pacheco, C.; Alcaraz, Y.; Delgado, F.; Vázquez, M. A.; Estrada-Soto, S. Eur. J. Med. Chem. 2013, 70, 669-676.

2. Alousi, A. A.; Farah, A. E.; Lesher, G. Y.; Opalka, C. J. Jr. Circ. Res. 1979, 45, 666-677. B) Azari, J.; Huxtable, R. J. Eur. J. Pharmacol. 1980, 67, 347-353.

3. Abadi, A. H.; Abouel-Ella, D. A.; Lehmann, J.; Tinsley, H. N.; Gary, B. D.; Piazza, G. A.; Abdel-Fattah, M. A. O. Eur. J. Med. Chem. 2010, 45, 90-97. b) Fan, X.; Feng, D.; Qu, Y.; Zhang, X.; Wang, J.; Loiseau, P. M.; Andrei, G.; Snoeck, R.; Clercq, E. D. Bioorg. Med. Chem. Lett. 2010, 20, 809-812.

4. Hanessian, S.; Therrien, E.; Zhang, J.; Otterlo, W. V.; Xue, Y.; Gustafsson, D.; Nilson, I.; Fjellstrom, O. Med. Chem. Lett. 2009, 19, 5429-5432.

5. Hartmann, R. W.; Reichert, M. Arch. Pharm. Pharm. Med. Chem. 2000, 333, 145-153

6. Bohn, M.; Kraemer, K. T.; Markus, A. US Pat; 0039030 A1, 2004.

7. Darvesh, S.; Magee, D.; Valenta, Z.; Martin, E. US Pat; 6544986 B2, 2003.

8. a) Soto, J. L.; Seoane, C.; Zamorano, P.; Rubio, M. J., Monforte, A.; Quinteiro, M. J. Chem. Soc., Perkin Trans. I, 1985, 1681-1685. b) Misic-Vukovic, M.; Mijin, D.; Radojkovic-Velickovic, M.; Valentic, N.; Krstic, V. J. Serb. Chem. Soc. 1998, 63, 8, 585-599. c) Paulvannan, K.; Chen, T. J. Org. Chem. 2000, 65, 6160-6166. d) Dave, C. G.; Shah, D. A.; Agrawal, Y. K. Ind. J. Chem. 2004, 43B, 4, 885-887. e) Alberola, A.; Calvo, L. A.; Ortega, A. G.; Ruiz, M. C. S. J. Org. Chem. 1999, 64, 9493-9498. f) Chen, Y.; Zhang, H.; Nan, F. J. Comb. Chem. 2004, 6, 684-693. g) Wang, S.; Tan, T.; Li, J.; Hu, H. Synlett 2005, 17, 2658-2660. h) Heravi, M. M.; Hamidi, H. J. Iran. Chem. Soc. 2013, 10, 265-273.

9. Xiang, D.; Wang, K.; Liang, Y.; Zhou, G.; Dong, D. Org. Lett. 2008, 10, 2, 345-348. 
10. Chun, Y. S.; Ryu, K. Y.; Ko, Y. O.; Hong, J. Y.; Hong, J.; Shin, H.; Lee, S-G. J. Org. Chem. 2009, 74, 7556-7558.

11. Ravindera, M.; Mahendar, B.; Mattapally, S.; Hamsini, K. H.; Reddy, T. N.; Rohit, C.; Srinivas, C. K.; Banerjee, S. K.; Rao, V. J. Bioorg. Med. Chem. Lett. 2012, 22, 6010-6015.

12. Chavan, S. S.; Degani, M. S. Catal. Lett., 2011, 141, 1693-1697.

13. a) Delgado, F.; Tamariz, J.; Zepeda, G.; Landa, M.; Miranda, R.; García, J. Synth. Commun. 1995, 25, 753-759. b) Obrador, E.; Castro, M.; Tamariz, J.; Zepeda, G.; Miranda, R.; Delgado, F. Synth. Commun. 1998, 28, 4649-4663. c) Alcerraca, G.; Sanabria, R.; Miranda, R.; Arroyo, G.; Delgado, F. Synth. Commun. 2000, 30, 1295-1301.

14. Vázquez, M. A.; Landa, M.; Reyes, L.; Miranda, R.; Tamariz, J.; Delgado, D. Synth. Commun. 2004, 34, 2705-2718.

15. Sánchez, A.; Hernández, F.; Cruz, P.; Alcaraz, Y.; Tamariz, J.; Delgado, F.; Vázquez, M. A. J. Mex. Chem. Soc. 2012, 56, 2, 121-127.

16. Flores-Conde, M. I.; Reyes, L.; Herrera, R.; Rios, H.; Vazquez, M. A.; Miranda, R.; Tamariz, J.; Delgado, F. Int. J. Mol. Sci. 2012, 13, 2590-2617.

17. Bhattacharyya, P.; Pradhan, K.; Paul, S.; Das, A. R. Tetrahedron Lett. 2012, 33, 4687-4691.

18. a) Pool, G. C.; Teuben, J. H. IR Radiation as a Heat Source in Vacuum Sublimation, in: Practical Organometallic Chemistry, Wayda, A. L.; Darensbourg, M. Y., Eds., Symposium Series 357, Washington, D. C. 1987, 30-33. b) Irradiation was made by an OSRAM R-20 bulb. This bulb operates at a voltage of $127 \mathrm{~V}$ and power of $250 \mathrm{~W}$. The R-20 bulb filament is a wire wound on a spiral type C. The lamp temperature is specified to be 2500 $\mathrm{K}$ and a lifetime of $500 \mathrm{~h}$. Construction materials determines the energy output characteristics of the lamp. The bulb emits a short wavelength in the near IR region. We are conducting a thorough study of the source of this lamp. Preliminary data indicate that the wavelength emitted by the lamp is $1255.6 \mathrm{~nm}$. These data are consistent with information found in the literature,[18c] and will be published soon. c) Shortwave Electric Infrared. The Facts, Copyright@ ITW BGK Finishing Systems 05/03. www.bgk.com.

19. a) Davidson, R. S., Safdar, A., Spencer, J. D., Robinson, B. Ultrasonic 1987, 24, 1, 35-39. b) Mason, T. J. Chem. Soc. Rev. 1997, 26, 443-451.

20. X-ray data has been deposited at the Cambridge Crystallographic Data Centre (Deposit number CCDC 970640). Crystal data and structure refinement of the compound $\mathbf{9 b}$ are included in Supplementary Information.

21. a) Abdel-Ghany, A.; Hazzaa, M.; Mohamad M.; Ghani, M.; Kassem, Z. Lett. Org. Chem. 2008, 5, 4, 316-318. b) Elkasaby, M. A.; Elshahed, F. Indian J. Chem., Sec B: 1981, 20B, 5, 428-31. c) Krauze, A. A.; Garalene, V. N.; Dubur, G. Ya. Khim. Farm. Zh. 1993, 27, 30-41. d) Hoffer, Max. US Pat; 2400045, 1946.

22. SHELXTL, v. 5.10; Bruker AXS, Inc.: Madison, WI, 1998. b) Sheldrick, G. M. Acta Crystallogr. 2008, A64, 112-122.

23. SHELX97, Programs for Crystal Structure Analysis, Release 97-2; Institüt für Anorganische Chemie der Universität: D-3400 Göttingen, Germany.

24. SIR92. Altomare, A.; Cascarano, G.; Giacovazzo, C.; Guagliardi, A. J. Appl. Crystallogr. 1993, 26, 343-350.

25. WinGX. Farrugia, L. J. J. Appl. Crystallogr. 1999, 32, 837-838.

26. a) PLATON. Spek, A. L. J. Appl. Crystallogr. 2003, 36, 7-13. b) ORTEP-3. Farrugia, L. J. J. Appl. Crystallogr. 1997, 30, 565. 